\section{(Original Artirlex.}

MEMORABILIA : EXTRACTS FROM MEDICAL NOTES MADE BY THE LATE HENRY INGERSOLL BOWDITCH, M.D., OF BOSTON.*

$$
\text { BY VINCENT Y. BOWDITCH, M.n., BOETON. }
$$

The title of my paper is the result of looking over a series of manuscripts prepared as a résumé of his "Life Work" by my father for his Harvard Class Report Book. I found among them several short articles which contained much that was interesting in giving the personal touch to various medical subjects, and I then conceived the thought of placing a few of them before this Association, the objects of which always had his cordial sympathy. In selecting these extracts I may be accused of going outside the strict limit of subjects supposed to be touched upon by our society; but as they bear upon the life work of one who took such keen interest in our transactions and who offered to us in $1889^{1}$ the last and perhaps the most picturesque paper of his life, I have felt justified in deviating slightly from the usual custom.

The paper I refer to was entitled "Open Air Travel as a Cure for Consumption," a record of the life of his own father subsequent to severe pulmonary hemorrhages at the age of thirty-five. Some of us will remember the picturesque account of the long buggy-ride taken by his father through New England in 1808, covering a period of many weeks after his illness; of the successful result, and the fact that he died, an old man, thirty years afterwards, of another disease, the cicatrix of the old pulmonary lesion having been found after death. The salient point of this interesting paper was the insistence upon the importance of fresh air, regular, judicious exercise and simple, nutritious diet, all elements of general hygiene, which seemed to have been insisted upon by a wise physician living in the early part of the last century and carried out faithfully by his patient. The paper has proved a classic in giving evidence of the truths contained therein, while couched in language that holds the attention as something unusual in its manner of expression.

One of his first notes refers to his translation of the great Louis' work upon "Gastro-Entérite" (Typhoid Fever) which he published in 1836. Incidentally he speaks of Louis' methods and of his deep affection for his great master. He writes in 1885 :-

"My first thought on my return from student life in Paris (1832-34) was to give to the English speaking people a translation of this great work, which. with the 'Numerical System' (of which the volumes are an admirable exposition), has had greater influence towards a more scientific study of Medicine than any work that has, in modern times, been published. 'Perpenden-

* Read before The American Climatological Association at Hartford, Conn., June 11, 1912.

1 Transactions of The American Climatological Association, 1889. dae, et numerandae Observationes' was the motto of the 'Sociêté Médicale d'Observation,' which Louis founded, and of which he was 'Perpetual President.' By the influence of that Society in Paris, and similar ones in other cities he hoped to introduce more accurate observations of disease and, in numbers, to express the frequency, etc., of every symptom and of the lesions found after death. None but those who loved the naked truth more than their own fancies or ill-recorded data could easily bear the criticisms made at the meetings; still less could they have a kind of grim satisfaction in them as vehicles of immense good to every one present, more especially to the reader himself. For many months I was a member of the Society, and under the teaching of this excellent man. His influence I feel now (1885) as great as ever it has been during my life, and it is seen in every medical paper I have written. The 'Société' considered me worthy to be one of 'elect.' At the reading of my first paper before it, there were, I think about twenty seated at a table of horse shoe form. Each one had paper and pencil before him. Louis, in the centre of us, presided. I gave the final summing up of the paper's short-comings. It was one of the sacred rules that each one should feel himself bound to notice every deficiency in the 'Observation' presented, and to openly give his criticisms. Anyone who feared injuring the feelings of the writer and should neglect this criticism would be deemed unworthy as a member. Any one 'thin skinned' enough to be hurt by the severest examination was considered a fool, totally unable to appreciate the fine tonic effect of a pure, friendly, but sharp, criticism from others; all equally desirous with himself of arriving at sacred truth. How well do I remember my first ordeal, and Louis' pungent critique upon a certain part of my paper, and his conclusion; that 'as Mons. Bowditch had not recorded certain data about the heart he might as well have omitted all mention of that organ.' I thought then and I still think that meeting one of the most refreshing and invigorating I had ever attended. It was really an intellectual 'bitter tonic,' and I was soon feeling prepared for another trial, with the determination to out-do myself. Louis, (dear friend, as he was) seemed to fear that the criticisms had, perhaps, been hard for me; and before the next meeting was called to order, he smiling said, 'Well, my dear, we attacked you severely last evening; but you must remember that we never can criticise anything that is not good.' Politesse Française! qu'elle est aimable!

" Under such influences, and in Louis' 'Clinique' daily I spent two years of the most delightful of my life. It was only a continuation of the same influences, when I undertook the translation of Louis' works." (1836)

The next rote refers to his experience in studying the development of the ova of the lymnaeus or common snail under the microscope. This work, exquisitely illustrated in pencil by his 
wife, gives evidence of the patience of both in watching for several seasons the gradual growth of these little creatures. He says :-

"A series of annual microscopic studies of the minute, transparent ova (of the snail), was not only a delightful study and illustration of the Gell Theory, but a constant source of religious inspiration far above creeds. I saw an egg shell, with its little mass of granules; apparently at rest, but really from the earliest hour of birth beginning its circular movements upon itself and also gyrations around within the shell. At first this movement was so slow that it could not be recognized save by placing it in a certain part of the field of vision, and examining again after the lapse of some minutes. As Agassiz admitted when I said it seemed like planetary law, and he replied, 'Yes, Doctor, it is the same that governs the Planetary bodies.' Out of these movements and its unseen 'principle of life' through cells and secondary cells inside of the larger ones, I saw organs develop themselves in most perfect beauty. What was more, I saw function showing itself in the unformed cells; for example in the heart, one of the most exquisite of structures, with its auricle and ventricle and its opening and closing auriculo-ven. tricular valve,-which it seemed as if I could auscult; as I do the sound of the human heart! I had become so acquainted with the various processes and the places in the midst of still unarranged cells, where the organ would appear, that, in fancy, I placed the perfect organ there. One day, when thus thinking and looking, a sudden contraction of the bunch of cells took place. I said, 'How Fancy deceives even our own senses! I must have been mistaken,' and the part rolled out of sight. On watching farther, however, and upon several occasions, I learned this fact that function is implanted in the future organ even before it is formed! I was able by having proper apparatus and a number of microscopes to show the gradual development of the little creature until by its spikey tongue, it tore its way into the external world,--not larger than the most minute grain of sand and only really recognizable by the microscope. My scientific knowledge and my religious nature were alike improved by this study. And I never heard or read a more eloquent series of sermons than were given by these scientific studies in the Springs of several successive years (1845-6-7-8)"

In the third note, which contains a therapeutic suggestion quite within the lines of our practice in this association, his allusion to Amos Twitchell, of Keene, N. H., one of the best of men and among the cleverest of physicians in the middle of the last century, has a quality which is of interest to our profession. In speaking of the Memoir of his friend which he was asked to prepare, he says :-

"Dr. T. was one of the most remarkable men I have met either in or out of the Profession.
He was a massive man in every way. He was the classmate and friend of Daniel Webster. As a surgeon, he was imperturbable; fertile of resources and in unexpected cases never at a loss. He would defy all the stereotyped rules of surgery, when he met an unusual accident. Instead of letting the patient die by the 'Providence of 'God' he would attempt, at least, to save him by the sagacity of man. His ability was never more splendidly shown than when he tied up the carotid artery, which previously good surgery forbade, and thereby not only saved the youthful sufferer, but gave a new practical rule for surgeons instead of an effete dogma, founded on theory rather than experience. At one time, he drove in his 'one hoss shay' in a circle, with a more than fifty-mile radius. $\mathrm{He}$ was so well known, and everywhere could claim a relay so promptly, that he would arrive as punctually at a great distance, as we now do by our railroad devices. He was a kindly man and yet such a hater of shams that he has left phrases behind him that sparkle with a spice of bitterness. 'That man cheated me,' he would say, 'worse than the Deacon would.' He was a great joker and even late in life practised jokes upon his townsmen when a fit occasion arose. He hated rum and tobacco and always was a great preacher against both, when surrounded by his friends and neighbors near the tavern, in early days, and at the depot during his later ones. He studied nature rather than books. For years, in the summer, I loved to meet him at Keene and listen to his words of practical wisdom, and to gain cheerfulness of spirit from his overflowing fund of humor. To him I owe the one recipe that scarcely ever fails me. It seems but yesterday I met him at the depot. I was just leaving for Boston after a visit of two weeks at that (then, certainly) delightful spot, Keene, N. H., famous, in my eyes, for its sweet homes of lovely and intelligent women and of solid men of sense and of whom Twitchell was 'primus inter pares.' Suddenly he said, 'If you ever have a rheumatic case of orthopnoea I want you to try a pill, I am sure you will find useful. I received it twenty-five years ago from Prof. Nathan Smith of New Haven. He had used it twenty-five years with great satisfaction.' I (H. I. B.) have used it at least thirty-five years*, so that the combination has a 'pedigree' of at least eighty-five years' use, by three men (I trust I may say) of common sense, and of large practice, and two of them (Smith and Twitchell) giants in their days. I have not known the remedy to fail wholly, in a case of orthopnoea, in which the heart's action was chiefly at fault, whether the difficulty was organic or functional. Some may smile at this proclamation of the virtues of a pill! 'Garrulous, foolish old man' may be the

* R Pulv. Digitalis, gr. x ; Pulv. Colchici, Sem., gr. xx ; Sod. Bi-Carb., gr. xxx; in 20 pills or powders, -one three times or more daily.

Let none but the purest articles be put up by perfectly honest druggists. 
thought of many. But the fact that, many times during these thirty-five years, I have been able to relieve most horrible distress and to restore to life and to the blessed power to work again in this world, is my excuse. Those acts have been among the most pleasant of my 'life work' in my profession to recall, and to Nathan Smith and Amos Twitchell I owe them all. I commend the combination to my successors in medicine in the full conviction that if used properly by intelligent physicians, I am bequeathing to them what will relieve an immense (amount) of human sufferings in all time to come. This may seem strong language; but, if my experience teaches me anything, it is true."

In his fourth note he wittily alludes to his "romantic" experience with a case of Diaphragmatic Hernia!

"A spice of what I call the 'Romance of Medical Practice' is connected with this pamphlet of 77 pages and which I prepared, 'con amore,' and did not know how to publish it until my friend, Dr. J. C. Dalton, the eminent physiologist, saw it in my hands and begged me to allow him to print it in the Buffalo Medical Journal of which he was Editor.

"The 'Romance' of it is as follows: In going, with a class of students around one of the surgical wards of the Massachusetts General Hospital in order to study healthy lung and heart sounds, I observed a young man lying down who had recently received a serious shock from a fall. As he was not suffering acute pain or apparent distress from the accident, I said to the students, ' $I$ am going to see whether the heart sounds are affected.' On ausculting the left side of the chest, I was astonished that instead of the beatings of the heart I heard nothing but sounds heard as, in the abdomen, of air in the intestines, while the heart was fairly dislocated to the right breast. Jumping too readily to a conclusion, I said, 'As the middle of the back is the seat of the injury, the diaphragm was probably ruptured and the intestines have fallen into the left thorax and now occupy the whole space usually taken up by the left lung and heart.' Of course it was of great interest to have an autopsy, when the patient died a few days afterwards, but the friend declared it should not be made. Late at night. by the light of a full moon, I entered the window of the autopsy room and by the same. found. what the absence of severe thoracic symntoms ought to have led me to the suspicion of perhaps, but certainly should have prevented my wrong diagnosis. viz., of recent rupture of the diaphragm :-I found almost complete absence of the left side of that important muscle. The case interested me very deeply, and I looked in books and journals, American and foreign. for others similar. Between 1610 and $1846 \mathrm{I}$ could find only eighty-eight cases. These I tabulated according to the 'Numerical Method' of my dear master Louis, and tried to extract from them all the truths they contained, anatomical, symptomatic, and causes; with diagnosis and prognosis as to the duration of life and treatment. I had a most delightful work, away from all the cares of common and pro. fessional life. I knew I was doing what had not been done before, and I knew that I must necessarily make a compact expression of the truth on the subject which would be worthy of respect and useful to any physician who should meet such a case. In my preface to the pamphlet (p. 77) that I printed from the Journal I closed with these words, 'I hope that the memoir will be useful to the future student of Diaphragmatic Hernia, but the examination of it can never afford anyone a tithe of the pleasure or profit the original preparation of it afforded me. July 4, 1853.' I could not but feel gratified to read in the London Lancet, Dec. 8, 1883, (30 years after the pamphlet was published) the following allusions to it and to myself. It is contained in an 'Address on the Place of Literature in Medicine,' read before the Medical Students Debating Society, at Owens College, Oct. 22, 1883 (London Lancet, Dec. 8, 1883; referred to by Philadelphia News, Jan. 12, 1884). The News had at the heading of its notice, 'An Englishman's Opinion of some American Work.' The writer of the Address (Dr. Cullingsworth) presents as his motto for the young men before him the noble words of Fichte, viz., "To this end am I called, to bear witness to the truth. My life, my fortune are but of little moment. The results of my life are of infinite moment, I am a priest of Truth; I am in her pay. I have bound myself to do all things, to venture all things; to suffer all things for her sake.' During the address Dr. C. pays a high tribute to the 'Numerical System.' Of course the words of a speaker of this high tone gratify me when he says, 'One of the best Medical Monographs with which I am acquainted is on Diaphragmatic Hernia by Dr. Bowditch of Boston, U. S. A. In this little book, scarcely larger than a pamphlet. is brought together all that, by the most patient research, could be found relating to the subject in Medical Literature during the period from 1610 to 1846 . Such work soon becomes intensely interesting as I can testify from my own experience; and that Dr. Bowditch found it so appears from the concluding sentence in his preface in which, after expressing a hope that it will be useful to the future students, he declares, - (here the writer quotes what is given above,- - the final words of my Preface). Truly the beginning and final outcome of my labor have a touch of the 'romantic' about them. Its commencement was truly such; for did I not 'meet it by moonlight alone?' Certainly no lover's heart ever palpitated more strongly than mine did at that hour."

The last note which I present to you touches upon Thoracentesis performed with an explor- 
ing trocha and suction pump, a subject and operation which doubtless brought Dr. Bowditch's name into prominence more than any other single work of his medical career. Although numerous papers have appeared on this subject, the following note throws such an interesting personal light upon the obstacles which any reformer has to meet and has so much pungent satire in its criticisms of those who opposed him at first, that I offer them to you now for your delectation.

"The history of my connection with this operation is as follows. I came from Europe holding the general views of the profession, viz., that it was not to be performed save in the most severe cases and generally when nature herself was 'pointing' as in abscess in other parts. But I was led, after a few years of practice and of seeing autopsies at the Massachusetts and Chelsea Hospitals, to believe professional opinion was incorrect. I saw not a few cases of pleuritic effusion end in death and nothing was found but simple serum filling one pleura and without a trace of disease elsewhere. said to myself, 'Cannot surgery be called to the relief of these sufferers?' I well remember one case, which I was sure was about to terminate fatally if relief were not obtained, and I urged the surgeon (one well-known and capable, and willing to be a surgeon in all other cases which were deemed feasible and right by the profession) to plunge into the chest a common trochar and, perhaps, save a life which otherwise was surely going to perish. He positively declined. After some months this patient died, worn out; and we found the left side of the chest (pleural cavity) stuffed full of simple serum. Not a trace of inflammation of the parts was found, or of disease elsewhere. This case and others like it made a deep impression, but I had no case under my own care. Moreover I shrunk from surgery, as painful to me. In 1848 I had one patient in my charge as one of the attending physicians at the Massachusetts General Hospital. He had one side of the chest distended, following acute pleurisy. On a consultation held by the physicians and surgeons I was in a minority of one. The others refused. No operation. Death occurred after months of suffering. Soon afterwards, having another case under my charge at the hospital, I determined to ask for no consultation, but to take the responsibility of having the operation of thoracentesis done. And it was done well (as always was the case with Dr. John Collins Warren) by eutting down and making a long incision between the ribs, and all before ether was thought of, so that intense suffering was the result. said to myself, 'You surgeons must find out some way easier than this. before I shall advise anyone to submit to it.' Meanwhile I was hearing of some few persons operating in Europe with a trochar and canula, and I determined to advise their use in a subsequent case. In 1849
I saw a child with evident effusion in one pleural cavity. She had had several severe attacks of difficult breathing. I advised puncture, but a surgeon having been summoned, declined to operate, and advised to wait for dyspnoea before doing so. Within forty-eight hours the child suddenly died in another fit of difficult breathing. I was allowed to plunge in a trochar after death, and pure pus gushed out. All these events confirmed my idea that an opening should be made in any case, on which $I$ had any opinion to give and that the common trochar should be used and not the scalpel. About this period I heard that Dr. Morrill Wyman of Cambridge (contrary to the advice of the seniors of the medical profession) had operated with the happiest result and with scarcely any pain with an exploring trochar, to which he had temporarily attached a strong English stomach pump which enabled him to draw fluid and, by turning a valve, discharged it with great ease. That was the instrument which I felt, although I had not seen it, which combined all that was needed to make an operation a perfect success,-Dowerful, simple, almost painless, and leaving no opening behind when finished. I determined to appeal to Dr. Wyman, though living in Cambridge, as no one in Boston could or would help me. In 1850, April 17, Dr. Wyman operated for me on one of my patients at Woburn. I then made up my mind that I could not always send four miles for a surgeon and though the act would be very unpleasant to me I must prepare to operate. My lessons on auscultation, my 'Young Stethoscopist', published in 1846-48, had led the profession to think, though a general practitioner, I was interested, especially, in thoracic diseases. I must be prepared to do all that was needed in such cases. The occasion came in October of the same year to test my ability to act up to my determination. A seaman from Wellfleet I found with cardiac disease, but also with one pleural cavity distended with fluid. $\mathrm{He}$ had terrible orthopnoea. (I should mention that a short time previously, I had had an instrument devised. whereby the canula could be screwed to the pump instead of with cork as Dr. Wyman had). So fearful was I, hawever, of ill success in that simple puncture that I took with me a young surgeon. a former student and friend of my own. To him I confided my fear of ill success and told him that if, at the last moment, I lost courage and bungled at the operation I wished him to take the trochar and plunge it into the throax 'capulo tenus.' Fortunately all went well and $I$ had conquered myself, and was a man. From that time to this, May 16, 1888, I have operated on 253 patients, and 395 punctures have been made. I believe I have contributed towards the reversal of the opinion of the medical public on the subject of Thoracentesis in the country and in England. I feel thankful that I have been able to fight (for it was a fight) 
against ridicule and contempt of able surgeons of Boston who could not believe that a non-surgeon could teach them anything. This opposition was carried to so great an extent that one of the Magnates, two years after the innocuousness of the operation and its great value were acknowledged by most other intelligent and unbiased men of the profession, actually caused the death of a little child, to whom he had called me, by delaying in the room below the little sufferer's, to talk of the 'dangerous' operation. While talking thus, an attendant burst into the room crying, 'For God's sake come up, we fear the child is dying.' We went up instantly, and indeed the last gasp was taken as we entered the room. Thus it is always with Truth,she has to fight her way. My Antislavery fight had given me some nerve, and this subject of Thoracentesis, simple and so beneficent as it seems now, strengthened me still more. I have often in both of these lines of life felt within myself a sort of what old poets would claim a 'divine afflatus,' and when opposition has come I have said, 'You must take it whether you will it or not. It is God's truth.'

"Since those early days, it will be seen by those who look into the histories of the various years, that I have been constantly at work upon the subject, and articles have been published by $m e$ in America and in Europe, and that I have made it the subject of addresses and communications to various societies,-American Medical Association, New York Academy of Medicine, and Massachusetts Societies, etc. I have in fact never let an opportunity escape of telling what I learned from year to year. My ideas have become widened, and I found out that the operation which I deemed 'Mediaeval'-like and cruel, viz., cutting. down between the ribs, as Dr. Warren did when I asked him to operate, is not only legitimate in some obstinate cases, but that a portion of one to four or five ribs may be taken, and to the real salvation of a patient. That a removal of parts of two ribs is consistent, with the vast advances made within the last few years. in surgery, I know is safe. I advised it in one case, which I think would never have recovered if that operation had not been done. As it happened, nothing but the external scar remained finally to mark the spot, the lung underneath being almost exactly like that on the other side; and no real contraction of the chest was the result. To say that I am not satisfied with this portion of my Life-Work would be untrue, and yet I see how I was led by a series of. circumstances of which I had not apparent control up to these pleasant and humane results. From these operations on the chest many lives will hereafter be saved who without them will die."

My father was never one to dispute with others over priority of claim to any act or deed of his. At every opportunity he acknowledged his debt to Dr. Morrill Wyman, of Cambridge, for the first suggestion of an instrument which in a modified form he used afterwards in hundreds of cases and forced upon the attention of the medical public. The fact that Dieulafoy, several years later, long after the first published accounts of my father's cases, claimed to be the first to use thoracentesis by aspiration when he introduced his excellent instrument to the world, was an instance of the singular indifference, to say the least, shown by some continental members of the profession to the work of their brothers outside of their own country. The fact was one only to cause amusement to my father and he never attempted to push his claim. It remained for his friend, the late Sir William T. Gairdner, of Edinburgh, who was one of the first to recognize the worth of my father's work, to mention in a memoir he wrote of his friend in the Edinburg Medical Journal of April, 1892, this singular lack of justice as exhibited by the eminent French physician.

Inasmuch as one or two medical papers have within recent years been published in which reference has been made to Dieulafoy as the inventor of thoracic aspiration, without any allusion whatever to the exhaustive work of my father upon the same subject years before, I feel I may be pardoned for showing some filial zeal in reviewing the subject again as a matter of justice.

The chief fact remains and that is after all the best to consider, apart from all personal considerations, - thoracentesis has brought relief to thousands of sufferers and saved lives without number. It is hard to believe that such a simple operation as it may be now regarded, to be performed by any practitioner of common sense and judgment, should have had to be forced upon the attention of a skeptical and prejudiced public of fifty or sixty years ago.

SOME OBSERVATIONS ON CASES OF PROSTATIC OBSTRUCTION PRESENTING OVERDISTENDED BLADDERS.*

BY ARTHUR L. CHUTE, M.D., BOSTON.

THE more I see of prostatic cases the more I am convinced that we as urinary surgeons have not sufficiently impressed upon the medical public the tremendous importance and significance of the overdistended bladder in cases of prostatic obstruction. In our enthusiasm for perfecting operative measures for the relief of this condition I feel that we have not put sufficient emphasis upon what one may call an even more fundamental point than the sort of technic that one shall employ in operation. The functional result we get after an operation for the relief of prostatic obstruction, I grant you, depends upon the correctness of our operative technic, but whether the patient lives or dies depends much

* Read at the annual meeting of the American Association of Genito-urinary Surgeons, Philadelphia, June 8, 1912. 